\title{
Ompok platyrhynchus, a new silurid catfish (Teleostei: Siluridae) from Borneo
}

\author{
HEOK HEE NG ${ }^{1} \&$ HEOK HUI TAN ${ }^{2}$ \\ ${ }^{1}$ Fish Division, Museum of Zoology, University of Michigan, 1109 Geddes Avenue, Ann Arbor, Michigan \\ 48109-1079,USA (heokheen@umich.edu) \\ ${ }^{2}$ Department of Biological Sciences, National University of Singapore, 10 Kent Ridge Crescent, Singapore \\ 119260
}

\begin{abstract}
Ompok platyrhynchus, a new species of silurid catfish is described from the Temburong River drainage in Brunei Darussalam, northern Borneo. Ompok platyrhynchus can be distinguished from all Southeast Asian congeners, except for O. hypophthalmus, O. rhadinurus and O. urbaini, in having 74-80 (vs. 40-70) anal-fin rays. Ompok platyrhynchus differs from O. hypophthalmus, $O$. rhadinurus and $O$. urbaini in lacking a distinct nuchal concavity, having a more slender body (13.517.7\% SL vs. 18.9-24.5), shorter snout (37.1-38.1\% HL vs. 39.4-47.5) and maxillary barbels (reaching to middle of pectoral fin vs. reaching to anterior third of anal fin), and more vertebrae (59-60 vs. 47-58).
\end{abstract}

Key words: Ompok, Siluridae, Borneo, Brunei, Temburong River, Southeast Asia

\section{Introduction}

The catfish genus Ompok Lacépede, 1803, refers to medium-sized silurid fishes found in inland waters throughout South and Southeast Asia. Bornbusch (1995) showed that Ompok, as currently understood, is probably paraphyletic. However, given the weak support for the monophyly of his clades, the taxonomy of Ompok is not stable enough to reassign any of the existing species to other genera.

During an ichthyological survey of the Temburong River in Brunei Darussalam, northern Borneo by the second author, an unusual silurid catfish with a broad, flattened head was obtained. Studies revealed this specimen to belong to an undescribed species, which is described herein as Ompok platyrhynchus, new species. 
Measurements were made point to point with dial calipers and data recorded to tenths of a millimeter. Counts and measurements were made on the left side of specimens whenever possible. Subunits of the head are presented as proportions of head length (HL). Head length and measurements of body parts are given as proportions of standard length (SL). Measurements follow those of $\mathrm{Ng}$ (2003). Asterisks after meristic counts indicate values for holotype.

Material examined in this study is deposited in the following institutions: Natural History Museum, London (BMNH), Collection of Maurice Kottelat, Cornol (CMK), Museum of Zoology, Field Museum of Natural History, Chicago (FMNH), Muséum National d'Histoire Naturelle, Paris (MNHN), Museum Zoologicum Bogoriense, Cibinong (MZB), Nationaal Natuurhistorisch Museum, Leiden (RMNH), University of Michigan, Ann Arbor (UMMZ), and the Zoological Reference Collection of the Raffles Museum of Biodiversity Research, National University of Singapore (ZRC).

\section{Ompok platyrhynchus sp. nov. (Figs. 1 \& 2a)}

Ompok sp. Choy \& Chin, 1994: 769.

Type material. Holotype: ZRC 48678, male, 78.9 mm SL; Borneo: Brunei Darussalam, Temburong district: Temburong basin, Belalong sub-basin; Sungai Esu, about 15 minutes upstream of Kuala Belalong Field Studies Centre (04³2'17.9"N 11509'35.2"E); H. H. Tan \& K. K. P. Lim, 6 Oct 2001.

Paratype: ZRC 31807, cleared and stained, $55.0 \mathrm{~mm}$ SL; Borneo: Brunei Darussalam, Temburong District, Sungai Belalong at Kuala Belalong Field Study Center; S. C. Choy, 27 July 1992.

Diagnosis. Ompok platyrhynchus can be distinguished from all Southeast Asian congeners, except for $O$. hypophthalmus, $O$. rhadinurus and $O$. urbaini, in having 74-80 (vs. 40-70) anal-fin rays. Ompok platyrhynchus differs from O. hypophthalmus, O. rhadinurus and $O$. urbaini in lacking a distinct nuchal concavity (Fig. 2), and having a more slender body (13.5-17.7\% SL vs. 18.9-24.5), shorter snout (37.1-38.1\% HL vs. 39.4-47.5) and maxillary barbels (reaching to middle of pectoral fin vs. reaching to anterior third of anal fin), and more vertebrae (59-60 vs. 47-58).

Description. Biometric data in Table 1. Body laterally compressed; maximum body depth located at pelvic-fin origin; head as broad as body and depressed. Dorsal profile of body gently convex.

Anterior profile of snout rounded. Anterior pair of nostrils tubular and anteromedial to maxillary barbel base. Posterior pair of nostrils bordered by fleshy dorsal and ventral membranes and posteromedial to maxillary barbel base. 


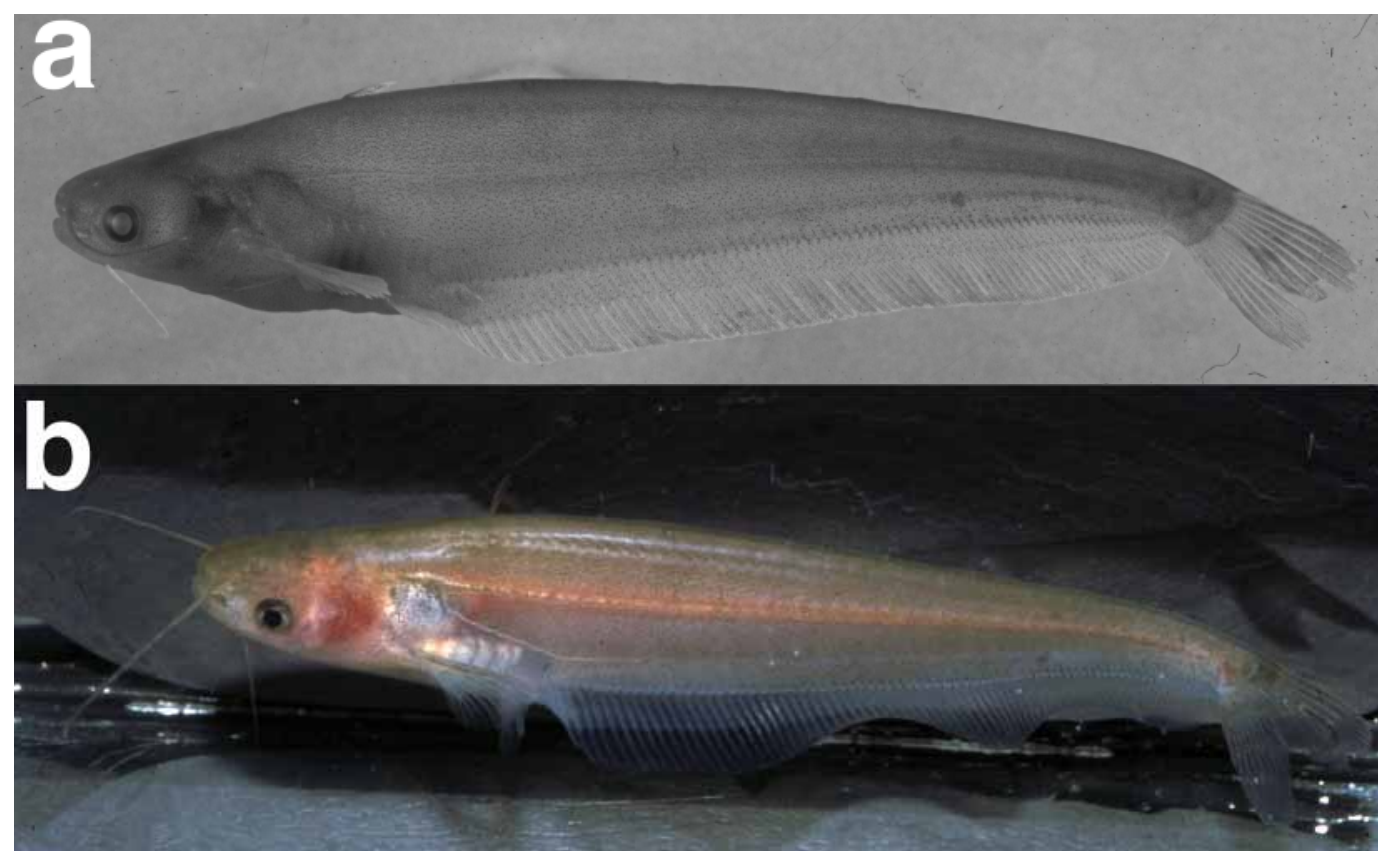

FIGURE 1. Ompok platyrhynchus, ZRC 48678, holotype, 78.9 mm SL; Borneo: Brunei Darussalam, Sungai Esu; a. preserved coloration; b. live coloration.

TABLE 1. Morphometric data for Ompok platyrhynchus.

\begin{tabular}{lcc}
\hline & Holotype & Paratype \\
\hline \% SL & 28.1 & \\
Predorsal length & 33.0 & 29.8 \\
Preanal length & 30.3 & 32.4 \\
Prepelvic length & 19.5 & 31.5 \\
Prepectoral length & 5.3 & 20.0 \\
Dorsal-fin length & 67.4 & 5.6 \\
Anal-fin length & 6.0 & 68.2 \\
Pelvic-fin length & 14.2 & 4.5 \\
Pectoral-fin length & 7.2 & 14.4 \\
Pectoral-spine length & 15.2 & 5.8 \\
Caudal-fin length & 17.7 & 14.9 \\
Body depth at anus & 5.1 & 13.5 \\
Caudal peduncle depth & 18.1 & 5.1 \\
Head length & 10.9 & 20.5 \\
Head width & 11.2 & 10.7 \\
Head depth & & 10.5 \\
\% HL & 37.1 & \\
Snout length & 54.5 & 38.1 \\
Interorbital distance & 17.5 & 49. \\
Eye diameter & 165.7 & 19.5 \\
Maxillary barbel length & 55.2 & 123.9 \\
Mandibular barbel length & & 57.5 \\
\hline
\end{tabular}


Mouth terminal; gape horizontal, small and extending halfway between maxillary barbel base and anterior orbital margin. Well-developed rictal lobes present, subtended by deep submandibular groove; upper rictal lobe without skin fold. Thin, broad supralabial fold extending from below orbit to maxillary barbel base.

Jaw teeth depressible and villiform. Premaxillary teeth in 4-5 irregular rows in narrow, gently curved rectangular bands. Dentary teeth in similar, slightly narrower bands narrowing posterolaterally, reaching from symphysis almost to mouth corners. First row of dentary teeth slightly visible when mouth is closed. Vomerine teeth in 2-3 rows in single ovoid patch straddling midline.

Two pairs of barbels, slightly flattened along entire length. Maxillary barbels reaching to middle of pectoral fin. Mandibular barbels (only outer pair present) reaching just beyond head. Eyes small, subcutaneous (without free orbital margin); located approximately midway on head and immediately behind supralabial fold. Dorsal orbital margin just visible dorsally; ventral quarter of orbital margin visible ventrally.

Gill membranes separate and overlapping, free from isthmus; gular fold well-developed and v-shaped. Branchiostegal rays 10 (1) or 11* (1). Gill rakers long and thin; anteriormost rakers on lower first arch widely spaced; $4+13$ (1) or $4+14 *(1)$.

a

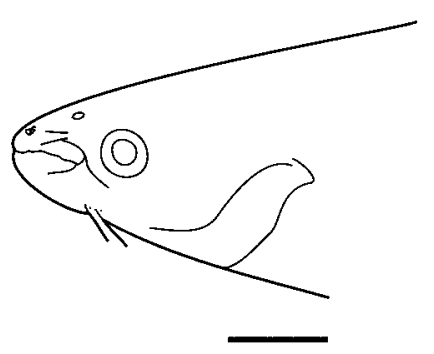

C

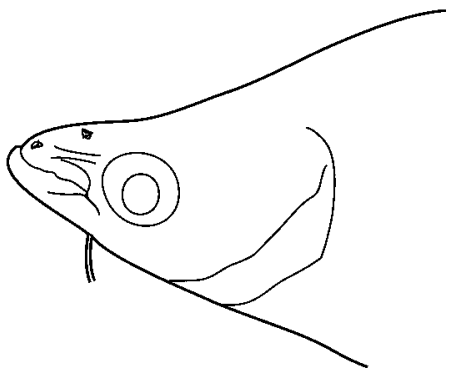

b

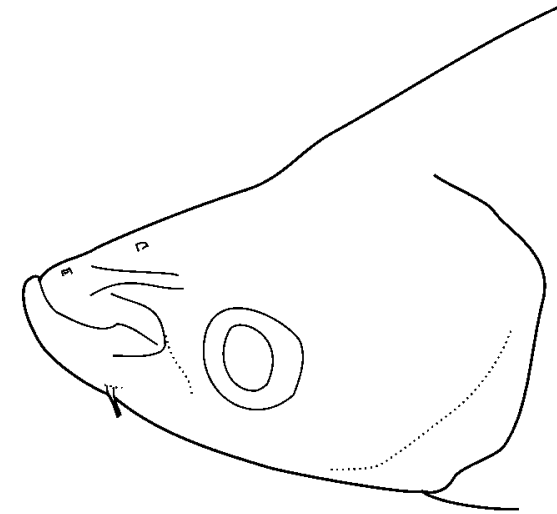

d

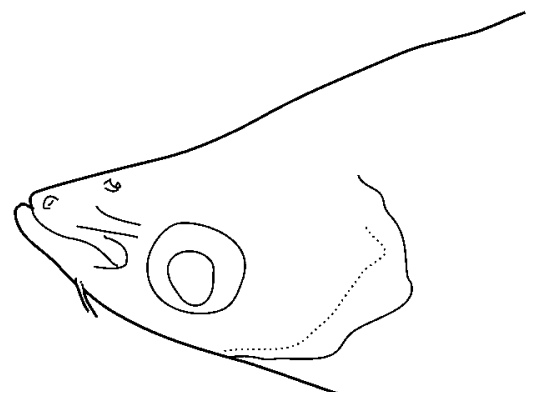

FIGURE 2. Lateral views of heads of: a. Ompok platyrhynchus, ZRC 48678, holotype, $78.9 \mathrm{~mm}$ SL; b. O. hypophthalmus, UMMZ155789, $126.0 \mathrm{~mm} \mathrm{SL}$; c. O. rhadinurus, UMMZ 155679, 80.9 $\mathrm{mm}$ SL and d. O. urbaini, UMMZ 234411, $85.5 \mathrm{~mm} \mathrm{SL}$. Scale bar represents $5 \mathrm{~mm}$. 
Dorsal fin small, with i,1 (2) rays. Depressed pectoral fin to origin of anal fin; distal margin broadly convex, with rounded tip. Third branched pectoral ray longest and fin with 10 (1) or 14* (1) rays. Proximal two-thirds of first pectoral-fin element co-ossified into a slender spine. Spine with shallow oblique striae on dorsal and ventral surfaces and with 5 serrations on posterior edge spanning the distal end of the ossified and proximal end of the flexible distal tip. Axillary pore small, located just above pectoral spine base. Depressed pelvic fin reaching to second or third anal-fin ray; distal margin convex with i,7 (2) rays. Distal margin of anal fin straight, with $74 *$ (1) or 80 (1) rays; separate from caudal fin. Integument over anal fin thickened proximally for two thirds of ray lengths; finray erector muscles attaching to base of fin rays, ventralmost extent of muscles defined by area of thickened integument. Caudal peduncle slender. Caudal fin deeply forked, lobes elongate and with rounded tips; upper lobe slightly longer; principal rays i,7,8,i (2).

Lateral line complete, extending to middle of caudal-fin base, with short branches along flanks directed posteroventrally. Urogenital papilla located immediately posterior to insertion of pelvic fin. Vertebrae $13+46=59$ or $14+46=60^{*}$.

Coloration. In 70\% ethanol: Body and head cream and diffusely pigmented. Light powdering of melanophores on all surfaces of head and body imparting a grayish color, somewhat less dense on belly and ventral surface of head. All fin rays with a light powdering of melanophores; fin membranes hyaline. Barbels with melanophores on dorsal half; ventral half unpigmented.

Color in life translucent (Fig. 1b)

Distribution. Known from the Temburong River drainage in northern Borneo (Fig. $3)$.

Habitat. The holotype of O. platyrhynchus was obtained from a small meandering stream about 3 meters at its widest and up to 1 meter deep. The water was clear and fast flowing over a rock and sand substratum, at parts bedrock that split the stratum and formed small cascades up to 3 meters high (Fig. 4). Syntopic fish collected include: Hampala bimaculata, Nematabramis steindachneri, Paracrossochilus acerus, Rasbora agyrotaenia, Tor tambra (Cyprinidae), Gastromyzon lepidogaster, Neogastromyzon sp., Parhomaloptera microstoma, Protomyzon sp. (Balitoridae), Pangio cf. mariarum (Cobitidae), Hemibagrus baramensis (Bagridae), Pterocryptis furnessi (Siluridae) and Macrognathus maculatus (Mastacembelidae).

Etymology. From the Greek platys, meaning flat, and rhynchos, meaning nose; in reference to the lack of a distinct nuchal concavity in this species. Used as a noun. 


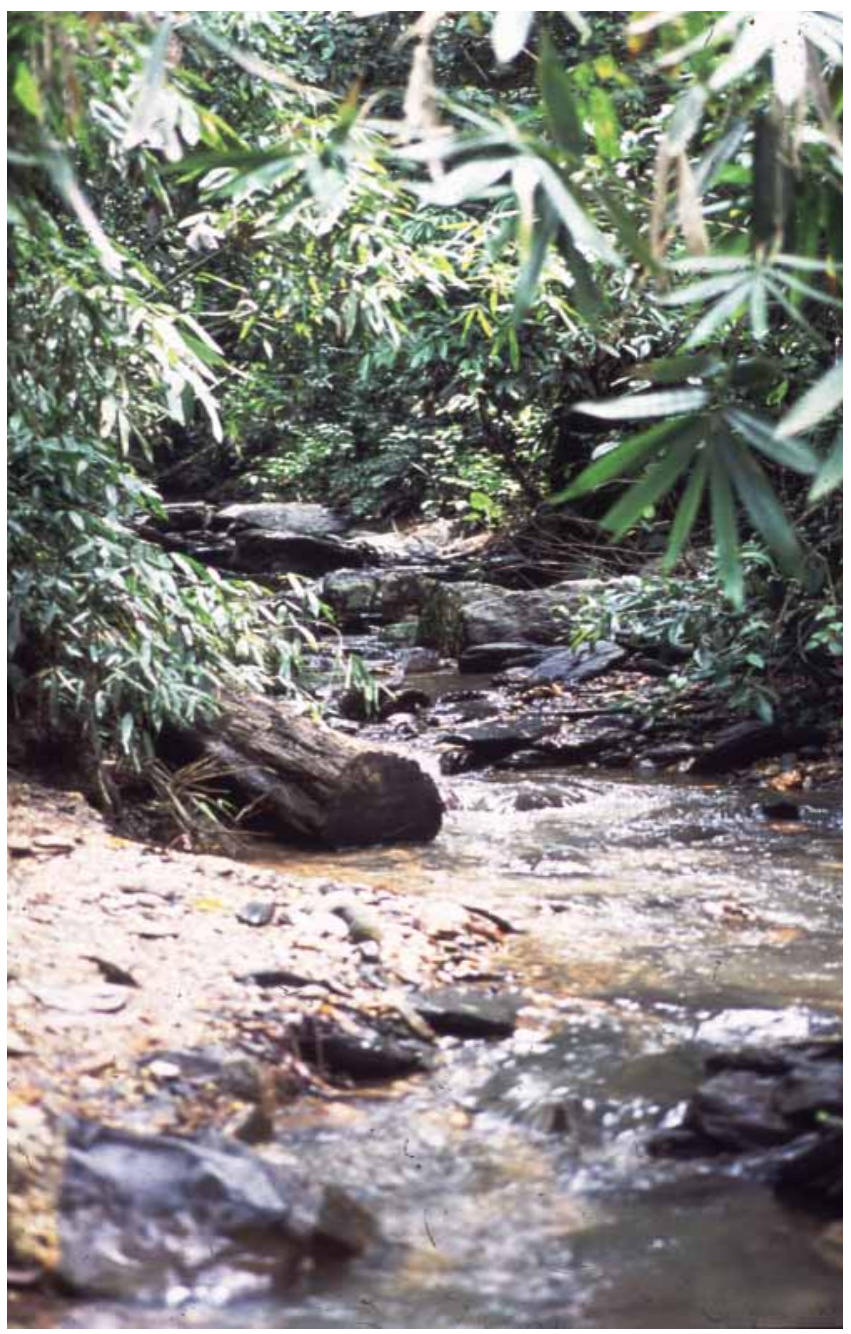

FIGURE 3. Type locality of Ompok platyrhynchus (Sungai Esu, Brunei Darussalam, Borneo).

\section{Discussion}

The highly elevated anal-fin ray counts of $O$. platyrhynchus easily distinguishes it from other species of Southeast Asian Ompok, except for O. hypophthalmus, O. rhadinurus and O. urbaini (Table 2).

The biometric differences between $O$. platyrhynchus and members of the O. hypophthalmus species group are summarized in Table 3. The differences observed in the body depth and snout length between O. platyrhynchus and O. hypophthalmus, O. rhadinurus and $O$. urbaini are not solely due to ontogeny. A bivariate analysis (ANCOVA) shows that the regression lines of the body depth (Fig. 5a) and snout length (Fig. 5b) on SL are signif- 
icantly different (with $\mathrm{P}=0.0137, \mathrm{P}<0.0001$, and $\mathrm{P}=0.011$ for body depths of $O$. hypoph-

thalmus, $O$. rhadinurus and $O$. urbaini respectively and $\mathrm{P}=0.034, \mathrm{P}=0.0347$, and $\mathrm{P}<0.0001$ for snout lengths of $O$. hypophthalmus, $O$. rhadinurus and $O$. urbaini respectively).

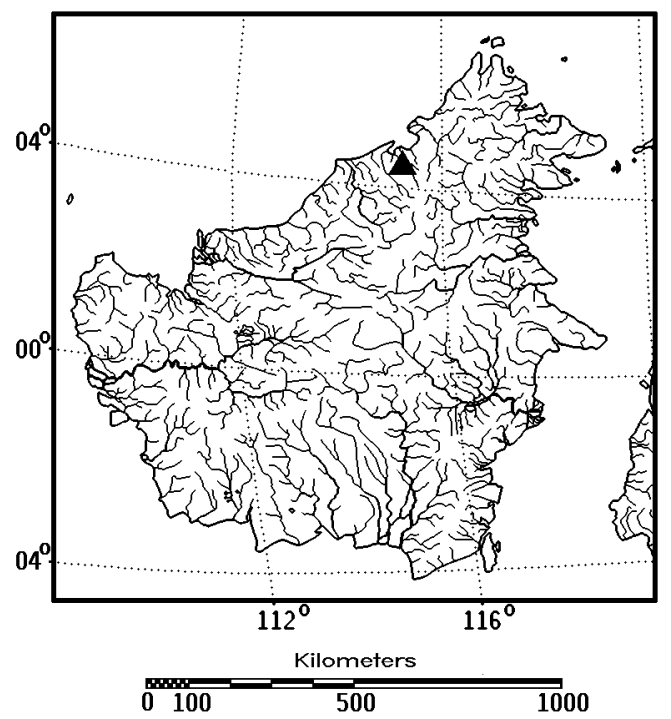

FIGURE 4. Distribution of O. platyrhynchus $(\boldsymbol{\Delta})$ in Brunei Darussalam, northern Borneo.

TABLE 2. Anal-fin ray counts for Southeast Asian Ompok.

\begin{tabular}{lc}
\hline Species & Anal-fin rays \\
\hline O. bimaculatus & $55-64$ \\
O. binotatus & $53-58$ \\
O. borneensis & $50-58$ \\
O. eugeneiatus & $58-62$ \\
O. fumidus & $53-60$ \\
O. hypophthalmus & $74-80$ \\
O. leiacanthus & $52-60$ \\
O. pinnatus & $53-58$ \\
$O$. platyrhynchus & $74-80$ \\
O. pluriradiatus & $63-70$ \\
O. rhadinurus & $76-85$ \\
O. sabanus & $55-66$ \\
O. urbaini & $65-71$ \\
$O$. weberi & $40-48$ \\
\hline
\end{tabular}


TABLE 3. Key biometric and meristic differences between $O$. platyrhynchus and members of the

\begin{tabular}{lccc}
\hline & Body depth at anus (\% SL) & Snout length (\% HL) & Vertebrae \\
\hline Ompok platyrhynchus & $13.5-17.7$ & $37.1-38.1$ & $59-60$ \\
O. hypophthalmus & $18.9-21.9$ & $42.1-44.7$ & $54-55$ \\
O. rhadinurus & $21.2-24.5$ & $39.4-47.5$ & $56-58$ \\
O. urbaini & $21.1-24.2$ & $42.7-44.0$ & $47-52$ \\
\hline
\end{tabular}
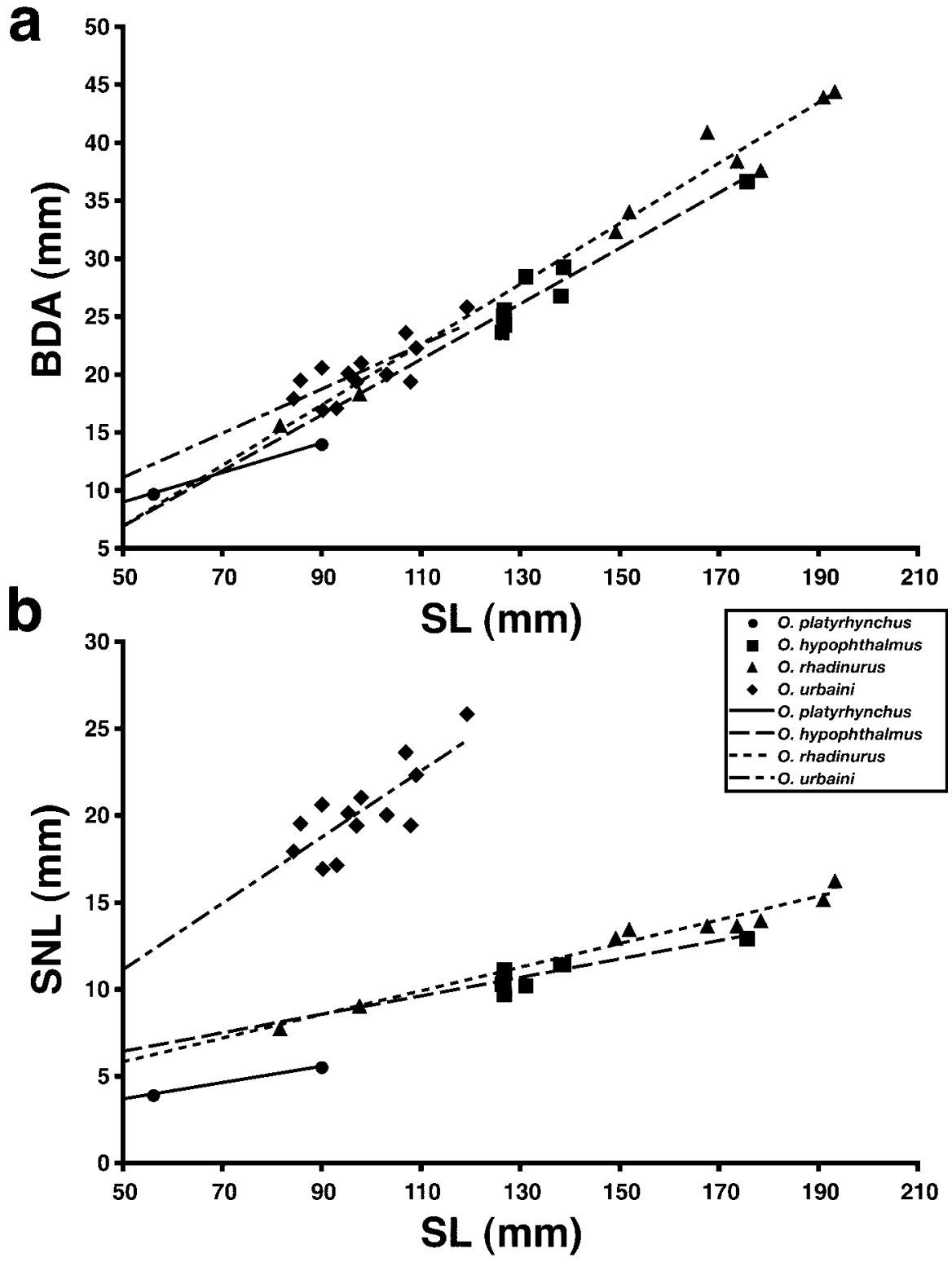

FIGURE 5. Biplots of biometric values for O. platyrhynchus, O. hypophthalmus, O. rhadinurus and $O$. urbaini: a. body depth at anus; b. snout length. 
Steindachner (1901) described Ompok borneensis from the Baram River. The species is known only from the holotype whose current disposition is unknown. Because of the similarity in the freshwater ichthyofauna of the Temburong and Baram River drainages, some comments on the identity of $O$. borneensis and more detailed comparison with $O$. platyrhynchus is necessary. Ompok borneensis is treated as a senior synonym of Ompok jaynei Fowler, 1905 here. Steindachner (1901) noted that the two median caudal-fin rays were shorter and thinner than the ones immediately adjacent to it ("Die mittleren 2 caudalstrahlen sind bedeutend kürzer und zarter als die nahe gelegenen längsten strahlen der flosse."), implying that the caudal fin is forked, and not rounded as illustrated in the original description (Steindachner, 1901: Pl. 18 Fig. 3). The caudal-fin shape, its confluence with the anal fin, the anal-fin ray count (Table 2) and the coloration (dark brown), indicate that $O$. borneensis is almost certainly conspecific with $O$. jaynei (also described from the Baram River). In addition to the more numerous anal-fin rays of $O$. platyrhynchus compared to O. borneensis (Table 2), the former species also has fewer dorsal-fin rays (2 vs. $4)$.

\section{Comparative material}

Ompok bimaculatus: RMNH 7811 (holotype of Wallago miostoma), $205.4 \mathrm{~mm}$ SL; Borneo: Tepoe. ZRC 45558 (9), 123.3-187.2 mm SL; Borneo: Kalimantan Timur, Mahakam River upstream of Kota Bangun.

Ompok binotatus: FMNH 94243 (holotype), 67.3 mm SL; FMNH 108813 (2 paratypes), 60.5-72.1 mm SL; Borneo: Kalimantan Barat, Sungai Mandai Kechil near its confluence with the Kapuas mainstream, 18 km WSW of Putussibau. CMK 6923 (11 paratypes), 48.1-90.5 mm SL; Borneo: Kalimantan Barat, Kapuas River drainage, right tributary of Sungai Sibau, about $3 \mathrm{~km}$ upstream of Putussibau.

Ompok borneensis: ZRC 2968 (14), 72.7-110.6 mm SL; Borneo: Sarawak, near Sibu. ZRC 40374 (1), $101.0 \mathrm{~mm}$ SL; Brunei: Tutong District, base camp at Tasik Merimbun, Sungai Meluncur (4³4'52.9"N 114²41'24.4"E). ZRC 40378 (1), 148.8 mm SL; Brunei: Tutong District, Tasik Merimbun (4³5'22.4"N 114²0'21.6"E).

Ompok eugeneiatus: CMK 16344 (1), 72.5 mm SL; Borneo: Kalimantan Barat, Sungai Letang near Kampung Kandung Suli. UMMZ 209881 (1), 91.3 mm SL; Borneo: Kalimantan Barat, Danau Piam near Ketungau, 38 km NNE of Sintang. ZRC 11819-11820 (2), 72.7-78.7 mm SL; Peninsular Malaysia: Pahang, Tasek Chini. ZRC 30458 (1), 92.8 mm SL; Peninsular Malaysia: Pahang, Sungai Chini. ZRC 38803 (3), 61.0-62.3 mm SL; Borneo: Kalimantan Barat, Danau Basuk, lake adjacent to Kapuas immediately downriver of Jongkong. ZRC 39036 (2), 82.7-84.5 mm SL; Sumatra: Riau, Sungai Bengkwang, tributary of Batang Kuantan (Indragiri River), 4 hours downstream of Rengat.

Ompok fumidus: ZRC 15094 (holotype), $113.8 \mathrm{~mm}$ SL; ZRC 15050-15052, 3 paratypes, 97.1-112.8 mm SL; Peninsular Malaysia: Selangor, North Selangor peat swamp 
forest, 43 km from Tanjung Malim. ZRC 2967 (1), $139.1 \mathrm{~mm}$ SL; Peninsular Malaysia: Pahang, Tasek Bera. ZRC 15048 (1), 118.8 mm SL; Peninsular Malaysia: Selangor, North Selangor peat swamp forest, stream at $0.7 \mathrm{~km}$ from $41 \mathrm{~km}$ marker on road to Tanjung Malim. ZRC 25112 (1), 112.8 mm SL; Peninsular Malaysia: Pahang, 16 km on KuantanMersing road. ZRC 27689-27692 (4), 92.2-113.0 mm SL; Peninsular Malaysia: Perak, Ulu Basir, N bank of Sungai Bernam.

Ompok hypophthalmus: UMMZ 155789 (6), 126.0-130.8 mm SL; Java: vicinity of Batavia. CMK 11856 (1), 137.8 mm SL; Borneo: Kalimantan Tengah, market in Puruk Cahu. ZRC 40036 (1), 175.3 mm SL; Borneo: Kalimantan Selatan, Banjarmasin.

Ompok leiacanthus: ZRC 38538 (neotype), 71.4 mm SL; Sumatra: Jambi, E end of Danau Arang Arang. BMNH 1863.12.4.85 (1), 119.7 mm SL; Bleeker material.

Ompok pinnatus: UMMZ 232679 (holotype), $80.5 \mathrm{~mm}$ SL; Cambodia: Tonle Sap at Kompong Chhnang, fishing lot 9 in second channel E of town. UMMZ 186749 (1 paratype), $67.1 \mathrm{~mm}$ SL; Thailand: Maharaj province, Koh Tong canal $17.5 \mathrm{~km} \mathrm{~N}$ of Ayutthaya. UMMZ 232375 (2 paratypes), 67.4-71.5 mm SL; Cambodia: Kandal, Prek Ta Pov, $11 \mathrm{~km} \mathrm{~S}$ of Phnom Penh.

Ompok pluriradiatus: MZB 5951 (holotype), $94.2 \mathrm{~mm}$ SL; CMK 7797 (15 paratypes), 73.1-111.7 mm SL; Borneo: Kalimantan Timur, a swift blackwater stream entering Mahakam River from the left side downriver of Muarapahu.

Ompok rhadinurus: ZRC 14897 (holotype), 190.8 mm SL; ZRC 14898 (1 paratype), $193.1 \mathrm{~mm}$ SL; Peninsular Malaysia: Selangor, North Selangor Peat Swamp Forest, irrigation canal on western boundary. UMMZ 155678 (1 paratype), $151.7 \mathrm{~mm}$ SL; UMMZ 155679 (2 paratypes), 80.9-94.2 mm SL; Sumatra: Musi River, Moeara [=Muara] Klingi. ZRC 41718 (2 paratypes), 166.3-179.6 mm SL; Sumatra: Jambi, Danau Arang Arang, brown water lake (1³7'32.0" S 10347'19.0"E). UMMZ 243278 (1), $149.0 \mathrm{~mm}$ SL; Sumatra: Jambi, Jalan Baru, between Payung Selincar \& Kompeh, (1³4'18.0" S $\left.103^{\circ} 39^{\prime} 1.0 " \mathrm{E}\right)$.

Ompok sabanus: FMNH 44828 (holotype), $131.6 \mathrm{~mm}$ SL; FMNH 44829 (11 paratypes), 101.6-117.8 mm SL; Borneo: Sabah, Lahad Datu district, Segama River at Segama Estate. CMK 9480 (2), 47.1-54.6 mm SL; Borneo: Kalimantan Timur, Sungai Tulit, about $1 \mathrm{~km}$ downriver from Semunad and small creek entering it. CMK 9514 (1), 49.8 mm SL; Borneo: Kalimantan Timur, Sungai Tulit between Semunad and 300m downriver. CMK 9492 (1), $115.5 \mathrm{~mm}$ SL; Borneo: Kalimantan Timur, Sungai Sebuku at and near Pembeliangan. ZRC 37635 (8), 75.2-111.7 mm SL; Borneo: Sabah, Kinabatangan River near Kampung Batu Puteh, Danau Biandum.

Ompok urbaini: MNHN 1966-706 (1 syntype) 181.0 mm SL; MNHN 1966-707, 1 ex., syntype, 165.0 mm SL; MNHN 1966-708, 1 ex., syntype, 112.6 mm SL; Cambodia: Tonle Sap. UMMZ 232360 (1), $92.2 \mathrm{~mm}$ SL; Cambodia: Kompong Chhnang, Tonle Sap at Kompong Chhnang fishing lot 9 in second channel east of town. UMMZ 232378 (5), 84.1-119.0 mm SL; UMMZ 234411 (2), 85.5-96.8 mm LS; Cambodia: Kandal, Prek Ta 
Pov, 13 km south of Phnom Penh. UMMZ 232427 (4), 90.0-107.7 mm SL; Cambodia:

Siem Reap, floating village at mouth of Siem Reap River. UMMZ 235389 (1), 108.8 mm

SL; Laos: Champasak, Mekong River at Ban Hang Khone, just downstream from Khone Falls.

Ompok weberi: BMNH 1994.12.16.228229 (2), 27.729.2 mm SL; Borneo: Kalimantan Tengah, Sungai Serendan. CMK 14802 (10), 21.6-34.5 mm SL; Borneo: Kalimantan Barat, Sungai Pinyuh, 8 km SE of Anjungan on road to Pontianank. ZRC 46124 (2), 23.0$32.1 \mathrm{~mm}$ SL; Borneo: Kalimantan Tengah, road from Pangkalanbun to Nipa between Kubu and Nipa.

\section{Acknowledgments}

We thank the following: Darrell Siebert (BMNH), Maurice Kottelat (CMK), Mary Anne Rogers (FMNH), Patrice Pruvost (MNHN), Martien van Oijen (RMNH), Doug Nelson (UMMZ) and Kelvin Lim (ZRC) for permission to examine material under their care; Zohrah Haji Sulaiman (University of Brunei Darussalam) and Mohamed Salleh (Kuala Belalong Field Study Centre), for providing logistical support to HHT. This work was funded by the Rackham School of Graduate Studies of the University of Michigan, the All Catfish Species Inventory (NSF DEB-0315963) and research grant R-154-000-062-112 of the National University of Singapore to Peter K. L. Ng.

\section{References}

Bornbusch, A.H. (1995) Phylogenetic relationships within the Eurasian catfish family Siluridae (Pisces: Siluriformes), with comments on generic validities and biogeography. Zoological Journal of the Linnean Society, 115, 1-46.

Choy, S.C. \& Chin, P.K. (1994) Freshwater fishes from the headwaters of the Belalong-Temburong river system, Brunei Darussalam, Borneo. The Raffles Bulletin of Zoology, 42, 757-774.

$\mathrm{Ng}$, H.H. (2003) A review of the Ompok hypophthalmus group of silurid catfishes with the description of a new species from South-East Asia. Journal of Fish Biology, 62, 1296-1311.

Steindachner, F. (1901) Fische. In: Kükenthal, W. (ed.) Ergebnisse einer zoologischen Forschungreise in den Molukken und Borneo. Abhandlungen der Senckenbergischen Naturforschenden Gesellschaft, 25, 408-464, pls. 17-18. 